American Journal of Animal and Veterinary Sciences 3 (3): 78-84, 2008

ISSN $1557-4555$

(C) 2008 Science Publications

\title{
Effects of Betaine Supplementation to Methionine Deficient Diet on Growth Performance and Carcass Characteristics of Broilers
}

\author{
${ }^{1}$ H. Sun, ${ }^{1}$ W.R. Yang, ${ }^{1}$ Z.B. Yang, ${ }^{2}$ Y. Wang, ${ }^{1}$ S.Z. Jiang and ${ }^{1}$ G.G. Zhang \\ ${ }^{1}$ Department of Animal Sciences and Technology, Shandong Agricultural University, Tai-an, \\ Shandong, P.R. China, 271018 \\ ${ }^{2}$ Agriculture and Agri-Food Canada, Lethbridge Research Centre, P.O. Box 3000, Lethbridge, \\ AB, Canada T1J 4B1
}

\begin{abstract}
Problem Statement: The efficacy of Methionine (Met) sparing effect of Betaine (BET) has been shown to be associated with dietary compositions, animal physiological stage and living conditions. This study was to determine the extent to which dietary Met could be replaced by BET in broiler chickens under the feeding conditions specific to Chinese poultry industry.Approach: A total of 900 day-old Arbor Acres broiler chicks were fed three corn-soybean meal-based starter rations (d 121) and grower rations (d 22-42) for a total of 42 days. Met levels in the diets were: Diet 1, Met content at the recommended level (Control); diet 2, Met level at $85 \%$ of the Control supplemented with BET at the level of 400 (starter) or 300 (grower) $\mathrm{mg} \mathrm{kg}^{-1} \mathrm{DM}$; Diet 3, Met level at $75 \%$ of the Control supplemented with BET at the level of 600 (starter) or 500 (grower) $\mathrm{mg} \mathrm{kg}^{-1} \mathrm{DM}$. The broilers were raised in a temperature controlled house with 3 pens (replicates) per dietary treatment. Results: In general, treatment had no effect on body weight, feed intake or feed efficiency. Concentrations of growth hormone and insulin-like growth factor- 1 in the serum of broilers fed Diet 3 were higher $(\mathrm{p}<0.05)$ than that of broilers of other treatments. Supplementation of BET at the level of replacing $25 \%$ of total Met increased $(\mathrm{p}<0.05)$ breast meat yield and protein content of breast meat and liver, but decreased $(p<0.05)$ abdominal fat yield and ether extract content of liver. Conclusions/Recommendations: Supplementation of BET to replace up to $25 \%$ of total dietary Met did not affect the growth performance but improved the carcass quality of the broilers. BET could be used to spare $25 \%$ of the total Met in broiler diet that was formulated based on the Feeding Standard of China.
\end{abstract}

Key words: Broiler, betaine, methionine, growth performance, carcass characteristics

\section{INTRODUCTION}

Dietary labile methyl groups were proposed to be nutrients by du Vigneaud et al. ${ }^{[1]}$. Methionine (Met), choline, Betaine (BET) and folic acid are all considered as methyl donors to body metabolic reactions and have been shown to compensate for the partial deficiency of labile methyl groups in corn-soybean-based $\operatorname{diets}^{[2-5]}$. Modern nutrition has revealed that Met is one of the most limiting amino acids that play a crucial role in body protein synthesis and therefore it would be beneficial to spare its function as an methyl donor. It has been shown that folic acid has to take methyl group before liberating methyl group and choline first has to be activated and then converted to betaine before methyl groups are liberated to fulfill methylation function ${ }^{[6]}$. In contrast, BET contains three methyl groups in its structure and donates these in several metabolic reactions. On a molecular weight basis, BET contains about 3.75 times the methyl groups of Met and therefore would be an effective compound to spare dietary Met as methyl donor.

However, the Met sparing effect of BET has been the subject of some controversy. Some studies have shown positive responses of animals to BET supplementation in met deficient diets, which included improved animal performance and carcass characteristics ${ }^{[7-11]}$. These responses were obtained when 1 part of BET was supplemented to replace 2 parts of dietary DL-Met. However, the Met sparing effect of BET was not observed in other studies ${ }^{[12,13]}$. It seems that the efficiency of Met sparing effect of BET is associated with dietary compositions, animal physiological stage and living conditions. The objective of this study was to

Corresponding Author: Yang, W.R., Department of Animal Sciences and Technology, Shandong Agricultural University, Tai-an, Shandong, P. R. China, 271018 
determine the effect of BET supplementation to a Met deficient diet on growth performance and carcass characteristics of broiler chickens under the feeding conditions specific to Chinese poultry industry.

\section{MATERIALS AND METHODS}

Animals and experimental design: Nine hundreds of day-old Arbor Acres (AA; mixed sex) broiler chickens obtained from a local hatchery were randomly distributed among 9 pens with 100 chickens per pen. The chicks in 9 pens were then randomly allocated to 3 dietary treatments that were arranged as a complete randomized block design. The experiment was conducted in 2 phases: starter (1-21 d) and grower (22$42 \mathrm{~d}$ ). All birds were fed corn-soybean meal based basal diets (Table 1) that were formulated to meet the nutrients requirement for chickens (NY/T 33-2004) of Feeding Standard of the People's Republic of China except for Met content. The 3 dietary treatments were: Diet 1: Met content at the recommended level (Control) with no BET supplementation; Diet 2: Met level at 85\% of the Control supplemented with BET at the rate of 400 (starter) or 300 (grower) $\mathrm{mg} \mathrm{kg}^{-1} \mathrm{DM}$; Diet 3: Met level at $75 \%$ of the Control supplemented with BET supplementation at the rate of 600 (starter) or 500 (grower) $\mathrm{mg} \mathrm{kg}^{-1} \mathrm{DM}$. Methionine content in each diet was achieved by supplementation of a commercial available methionine product (DL-Methionine) to the basal diet. The amounts of BET supplemented to Diets 2 and 3 were calculated on the basis of 1 BET replacing 2 Met as methyl donors to compensate for the Met deficiency in these two diets. Betaine hydrochloride (Weifang Sunwin Chemicals Co., Ltd, China) was used as the source of BET. The treatments and contents of Met and BET of each diet were summarized in Table 2. Each diet was pelleted in one batch, stored in covered containers and was used for the entire experimental period.

Chicks were housed in a temperature-controlled room with raised wire floor. Room temperature was maintained at $35^{\circ} \mathrm{C}$ for the first $3 \mathrm{~d}$ and then gradually reduced to $24^{\circ} \mathrm{C}$ by the rate of $2^{\circ} \mathrm{C}$ every 3 days. Feed were provided for ad libitum intake and the birds had free access to water throughout the entire experimental period. Light was provided $24 \mathrm{~h}$ continuously with overhead incandescent lighting by 10 lux during the first $2 \mathrm{wk}$ period of the experiment and was then decreased gradually $\left(2 \mathrm{~h} \mathrm{day}^{-1}\right)$ to $20 \mathrm{~h}$ daily by wk 3 and maintained at this level till the end of the experiment.

Growth and carcass measurements: Body Weight (BW), feed intake (dry matter basis) and mortality of each pen were recorded weekly and Average Daily Gain
Table 1: Composition (\%) and nutrient content of the experiment basal diets ${ }^{2}$

\begin{tabular}{lrc}
\hline Ingredient (\%) & Starter & Grower \\
\hline Corn & 48.94 & 55.52 \\
Wheat-middlings & 10.00 & 10.00 \\
Peanut meal & 12.00 & 11.00 \\
Soybean meal, CP 43\% & 10.00 & 4.00 \\
Cottonseed protein & 4.00 & 4.00 \\
Cottonseed meal & 7.00 & 7.00 \\
Corn protein & 2.00 & 1.50 \\
Animal oil & 1.50 & 2.50 \\
Lysine & 0.40 & 0.51 \\
Threonine & - & 0.05 \\
Dicalcium phosphate & 1.00 & 0.80 \\
Phytase & 0.01 & 0.01 \\
Limestone & 1.70 & 1.70 \\
Salt & 0.25 & 0.25 \\
1\%Premix & 1.00 & 1.00 \\
Calculated composition & & \\
Methionine (\%) & 0.28 & 0.24 \\
Crude protein (\%) & 21.00 & 18.60 \\
Metabolizable Energy (Kcal $\cdot \mathrm{kg}^{-1}$ ) & 2869 & 2979 \\
Calcium (\%) & 0.98 & 0.87 \\
Total phosphorus (\%) & 0.71 & 0.63 \\
\hline
\end{tabular}

${ }^{\mathrm{z}}$ Nutrient level of the diets was based on feeding standard of chicken of the People's Republic of China (NY/T 33-2004)

${ }^{\mathrm{Y}}$ Premix supplied the following amounts of vitamin and minerals to per kg of diet for age of 1-21 d: vitamin A, $15300 \mathrm{IU}$; vitamin $\mathrm{D}_{3}$, $3740 \mathrm{IU}$; vitamin E , $40.8 \mathrm{IU}$; vitamin $\mathrm{K}_{3}, 5.1 \mathrm{mg}$; thiamin, $3.4 \mathrm{mg}$; riboflavin, $10.2 \mathrm{mg}$; vitamin $\mathrm{B}_{6}, 5.1 \mathrm{mg}$; vitamin $\mathrm{B}_{12}, 0.0204 \mathrm{mg}$; choline chloride, $1,000 \mathrm{mg}$; pantothenic, $15.3 \mathrm{mg}$; niacin, $61.2 \mathrm{mg}$; biotin, $0.204 \mathrm{mg}$; folic acid, $1.7 \mathrm{mg}$; Mn, $108 \mathrm{mg}$; Fe, $100 \mathrm{mg}$; Zn, 88 $\mathrm{mg}$; $\mathrm{Cu}, 9.6 \mathrm{mg}$; I, $0.374 \mathrm{mg}$ and Se, $0.224 \mathrm{mg}$; and for age of $22-42$ d: Vitamin A, $13500 \mathrm{IU}$; vitamin $\mathrm{D}_{3}, 3300 \mathrm{IU}$; vitamin E, $36 \mathrm{IU}$; vitamin $\mathrm{K}_{3}, 4.5 \mathrm{mg}$; thiamin, $3 \mathrm{mg}$; riboflavin, $9 \mathrm{mg}$; vitamin $\mathrm{B}_{6}, 4.5$ $\mathrm{mg}$; vitamin $\mathrm{B}_{12}, 0.018 \mathrm{mg}$; choline chloride, $800 \mathrm{mg}$; pantothenic, $13.5 \mathrm{mg}$; niacin, $54 \mathrm{mg}$; biotin, $0.18 \mathrm{mg}$; folic acid, $1.5 \mathrm{mg}$; Mn, 108 $\mathrm{mg}$; Fe, $100 \mathrm{mg}$; Zn, $88 \mathrm{mg}$; Cu, $9.6 \mathrm{mg}$; I, $0.374 \mathrm{mg}$ and Se, 0.224 $\mathrm{mg}$

(ADG), Average Daily Feed Intake (ADFI) and Feed: Gain $(\mathrm{F}: \mathrm{G})$ were calculated at the ages of 21 and $42 \mathrm{~d}$. On d 21 and 42 of the feeding trial, nine birds per treatment were randomly picked out ( 3 per pen) after an overnight $(12 \mathrm{~h})$ fast, weighed and sacrificed to evaluate carcass characteristics according to the procedure described by $\mathrm{Wang}^{[14]}$. Prior to being slaughtered, birds were individually weighed and blood sample $(5.0 \mathrm{~mL})$ was taken from wing vein of each bird into eppendorf tubes containing coagulant (Haimen city, Jiangsu province, P. R. China). The blood samples were immediately centrifuged $\left(1744 \times \mathrm{g}, 10 \mathrm{~min}, 4^{\circ} \mathrm{C}\right)$ with a low speed table centrifuge (80-2B, Shanghai, P. R. China) and the serum was stored at $-20^{\circ} \mathrm{C}$ in sealed container till analyzed. The serum samples were analyzed for Growth Hormone (GH) and Insulin-like Growth Factor-1 (IGF-1) with radioimmunoassay method. All samples were analyzed in one batch to avoid inter-assay variations. 
American J. Animal \& Vet. Sci., 3 (3): 78-84, 2008

Table 2: Arrangement of treatments and amounts $\left(\mathrm{mg} \mathrm{kg}^{-1} \mathrm{DM}\right)$ of Methionine (Met) and betaine supplemented to each diet

\begin{tabular}{|c|c|c|c|c|c|c|c|c|}
\hline \multicolumn{5}{|c|}{ Starter } & \multicolumn{4}{|c|}{ Grower } \\
\hline & $\begin{array}{l}\text { Met } \\
\text { Basal diet }\end{array}$ & $\begin{array}{l}\text { Met } \\
\text { Supplement }\end{array}$ & $\begin{array}{l}\text { Total } \\
\text { Met }\end{array}$ & $\begin{array}{l}\text { Betaine } \\
\text { Supplement }\end{array}$ & $\begin{array}{l}\text { Met } \\
\text { basal diet }\end{array}$ & $\begin{array}{l}\text { Met } \\
\text { Supplement }\end{array}$ & $\begin{array}{l}\text { Total } \\
\text { Met }\end{array}$ & $\begin{array}{l}\text { Betaine } \\
\text { Supplement }\end{array}$ \\
\hline Diet $1^{Z}$ & 2800 & 2000 & 4800 & 0 & 2400 & 1600 & 4000 & 0 \\
\hline Diet 2 & 2800 & 1200 & 4000 & 400 & 2400 & 1000 & 3400 & 300 \\
\hline Diet 3 & 2800 & 800 & 3600 & 600 & 2400 & 600 & 3000 & 500 \\
\hline
\end{tabular}

Table 3: Body weigh (BW), average daily gain (ADG), average daily feed intake (ADFI), feed:gain ratio (F:G) and mortality of broilers chicken fed experimental diets during a 42-d period of feeding experiment

\begin{tabular}{|c|c|c|c|c|}
\hline & Control $^{\mathrm{z}}$ & Diet 2 & Diet 3 & SEM $^{\mathrm{y}}$ \\
\hline \multicolumn{5}{|l|}{$\overline{\mathrm{BW}(\mathrm{g})}$} \\
\hline $1 \mathrm{~d}$ & 46 & 46 & 46 & 0.750 \\
\hline $21 \mathrm{~d}$ & $657^{\mathrm{b}}$ & $695^{\mathrm{a}}$ & $680^{\mathrm{ab}}$ & 9.350 \\
\hline $42 \mathrm{~d}$ & 2414 & 2420 & 2425 & 39.680 \\
\hline \multicolumn{5}{|c|}{$\operatorname{ADFI}\left(\mathrm{g} \mathrm{d}^{-1}\right)$} \\
\hline $1-21 d$ & 46.5 & 47.8 & 46.6 & 0.530 \\
\hline $1-42 \mathrm{~d}$ & $103.7^{\mathrm{a}}$ & $103.5^{\mathrm{a}}$ & $99.5^{\mathrm{b}}$ & 0.920 \\
\hline \multicolumn{5}{|c|}{$\operatorname{ADG}\left(\mathrm{g} \mathrm{d}^{-1}\right)$} \\
\hline $1-21 d$ & $29.1^{\mathrm{b}}$ & $31.0^{\mathrm{a}}$ & $30.2^{\mathrm{ab}}$ & 0.460 \\
\hline $1-42 d$ & 57.5 & 57.6 & 57.7 & 0.950 \\
\hline \multicolumn{5}{|l|}{$F: G$} \\
\hline $1-21 d$ & 1.60 & 1.54 & 1.54 & 0.024 \\
\hline $1-42 d$ & 1.84 & 1.83 & 1.76 & 0.037 \\
\hline \multicolumn{5}{|c|}{ Mortality (\%) } \\
\hline $1-21 d$ & 1.30 & 1.30 & 1.00 & 0.270 \\
\hline $1-42 d$ & 2.30 & 2.00 & 1.70 & 0.540 \\
\hline
\end{tabular}

${ }^{\mathrm{z}}$ Please see Table 2 for the description of dietary treatment

${ }^{\mathrm{y}}$ SEM, standard error of means

a,b: Within a row, means without a common superscript letter differ $(\mathrm{P}<0.05)$

The birds were slaughtered after blood samples taken and the carcass plucked to determine Carcass Weight $(\mathrm{CW})$. Intestines, windpipe, reproductive organ, gall bladder, spleen, oesophagus and content and cuticle of gizzard were then removed and semi-eviscerated carcass weight was obtained. The semi-eviscerated carcass was further processed to remove head, neck, legs, heart, liver, proventriculus, gizzard and abdominal fat to obtain the eviscerated weight. Abdominal fat including the fat that manually excised from the abdominal cavity (i.e., fat adhering to the gizzard, surrounding the bursa of fabricius, the cloaca and adjacent muscles) and breast meat was weighed after separation. Sub-samples were taken from liver and breast meat and stored at $-20^{\circ} \mathrm{C}$ for subsequent analyses of Crude Protein (CP) and Ether Extract (EE) content $^{[15,16]}$. Yield of Abdominal Fat (AFY), Carcass Yield (CY), Semi-Eviscerated Yield (SEY) and Eviscerated Yield (EY) were determined as percentage of live body weight at slaughtering, whereas Breast
Meat Yield (BMY) was calculated as percentage of the eviscerated weight. This study was performed in accordance with local ethical guidelines.

Statistical analysis: Data were statistically analyzed by one-way ANOVA using GLM procedure of SAS ${ }^{[17]}$ with individual pen as statistical unit. Differences among dietary treatment were compared using Duncans multiple range tests. A significance level of $p<0.05$ was used.

\section{RESULTS}

Growth performance: Broiler chickens consumed Diet 2 had higher $(\mathrm{p}<0.05) \mathrm{BW}$ and ADG compared to the broilers consumed Control diet, whereas this difference was not observed between birds ate Control diet and Diet 3 during the first 21-d experiment (Table $3)$. All broiler chickens had similar $(\mathrm{p}>0.05) \mathrm{BW}$ at the end of 42-d experiment and similar ( $p>0.05)$ ADG over the entire experiment. On the contrary, all birds had similar ADFI during the starter phase (1-21 d) and F: G in two phases regardless of the dietary treatments. However, broiler chickens consumed Diet 3 had lower $(p<0.05)$ ADFI compared to the broilers consumed Control diet and Diet 2. Furthermore, no significant difference was observed in mortality among treatments for birds during the entire experimental period.

GH and IGF-1: Birds consumed Diet 3 had highest levels of serum GH and IGF-1 on both 21 and $42 \mathrm{~d}$ of ages (Table 4). Supplementation of BET to diet with $25 \%$ Met deficiency increased $(\mathrm{p}<0.05)$ serum concentrations of GH at $42 \mathrm{~d}$ and IGF-1 at 21 and $42 \mathrm{~d}$ of ages. However, birds consumed Diet 2 (BET supplement to $15 \%$ Met deficient diet) had similar serum concentrations of GH and IGF-1 ( $p>0.05)$ to the Control birds regardless of the age.

Carcass characteristics: Carcass characteristics of broiler chickens as affected by dietary treatments were 
American J. Animal \& Vet. Sci., 3 (3): 78-84, 2008

Table 4: Concentration of Growth Hormone (GH) and insuline-like growth factor-1 (IGF-1) in the serum of broiler chickens at 21 or $42-$ d of age

\begin{tabular}{|c|c|c|c|c|}
\hline & Diet $1(\text { Control })^{z}$ & Diet 2 & Diet 3 & SEM $^{\mathrm{y}}$ \\
\hline \multicolumn{5}{|c|}{$\overline{\mathrm{GH}}\left(\mathrm{ng} \mathrm{mL} \mathrm{mL}^{-1}\right)$} \\
\hline $21 \mathrm{~d}$ & 1.11 & 1.17 & 1.37 & 0.174 \\
\hline $42 \mathrm{~d}$ & $1.14^{\mathrm{b}}$ & $1.16^{\mathrm{b}}$ & $1.61^{\mathrm{a}}$ & 0.212 \\
\hline \multicolumn{5}{|c|}{ IGF-1 (ng mL $\left.{ }^{-1}\right)$} \\
\hline $21 \mathrm{~d}$ & $10.83^{\mathrm{b}}$ & $14.17^{\mathrm{b}}$ & $19.39^{\mathrm{a}}$ & 2.543 \\
\hline $42 \mathrm{~d}$ & $19.96^{\mathrm{b}}$ & $19.38^{\mathrm{b}}$ & $26.20^{\mathrm{a}}$ & 0.870 \\
\hline
\end{tabular}

Table 5: Carcass Yield (CY), Semi-Eviscerated Yield (SEY), Eviscerated Yield (EY), Breast Meat Yield (BMY) and Yield of Abdominal Fat (AFY) of broilers chicken slaughtered at 21 or $42-d$ of age

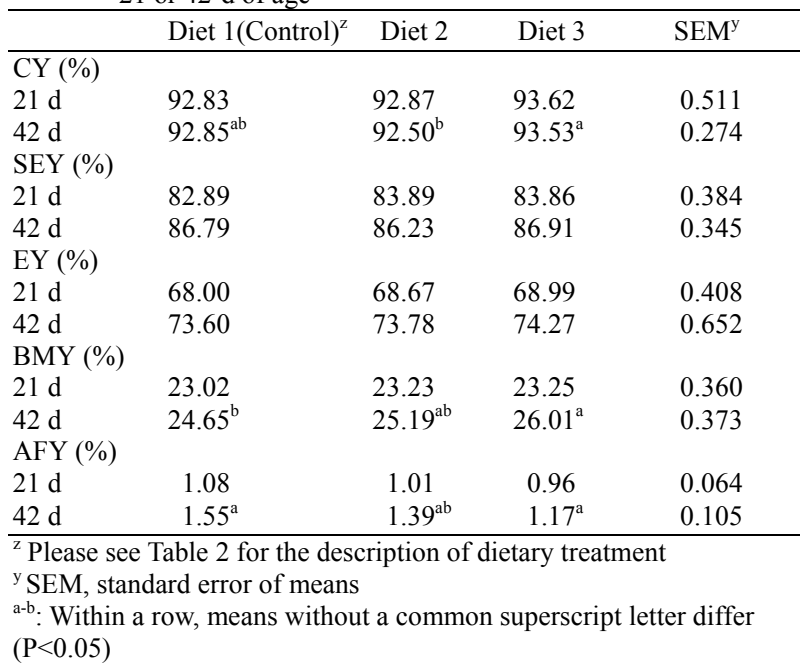

summarized in Table 5. Carcass yield of birds consuming Diet 3 was higher $(p<0.05)$ than that of birds consuming Diet 2 at $42 \mathrm{~d}$ of age, but was similar $(p>0.05)$ to other groups at $21 \mathrm{~d}$ of age. All birds slaughtered had similar SEY, EY regardless of dietary treatments or slaughter ages. Supplementation of BET to diet of $25 \%$ Met deficiency increased $(\mathrm{p}<0.05)$ BMY but decreased $(\mathrm{p}<0.05)$ AFY (Diet 3 vs. Control) at $42 \mathrm{~d}$ of age only. The similar trend, however, was not observed when BET was supplemented to diet of $15 \%$ Met deficiency (Diets 2 vs. Control).

Dietary treatment had no effect $(p>0.05)$ on contents of $\mathrm{CP}$ and $\mathrm{EE}$ in breast meat of birds at $21 \mathrm{~d}$ of age (Table 6). At $42 \mathrm{~d}$ of age, however, breast meat of birds consuming Diet 3 had higher $(p<0.05)$ contents of $\mathrm{CP}$ and EE than the birds consuming Control diet. Similarly, CP content in the liver sample of broilers fed Diet 3 was also higher $(p<0.05)$ than that of broilers fed Control diet, Diet 2 at both ages. On the contrary, the EE content of the liver was lower $(p<0.05)$ for broilers fed Diet 3 than for broilers fed other diets at the age of $42 \mathrm{~d}$.
Table 6: Contents (\%, DM basis) of crude protein and ether extract in Breast Meat (BM) and liver of broiler chickens slaughtered at 21 or $42-d$ age

\begin{tabular}{lcccc}
\hline & Diet 1(Control) & Diet 2 & Diet 3 & SEM $^{\mathrm{y}}$ \\
\hline Crude protein & & & & \\
BM (21 d) & 78.60 & 79.32 & 79.02 & 0.807 \\
BM (42 d) & $78.96^{\mathrm{b}}$ & $80.26^{\mathrm{ab}}$ & $81.94^{\mathrm{a}}$ & 0.734 \\
Liver (21 d) & $71.93^{\mathrm{b}}$ & $72.11^{\mathrm{b}}$ & $75.39^{\mathrm{a}}$ & 0.398 \\
Liver (42 d) & $67.58^{\mathrm{c}}$ & $69.01^{\mathrm{b}}$ & $69.45^{\mathrm{a}}$ & 0.376 \\
Ether extract & & & & \\
BM (21 d) & 4.39 & 4.09 & 5.54 & 0.539 \\
BM (42 d) & $3.45^{\mathrm{b}}$ & $3.18^{\mathrm{b}}$ & $4.56^{\mathrm{a}}$ & 0.263 \\
Liver (21 d) & $10.50^{\mathrm{a}}$ & $9.66^{\mathrm{a}}$ & $5.41^{\mathrm{b}}$ & 0.871 \\
Liver (42 d) & $17.40^{\mathrm{a}}$ & $16.16^{\mathrm{b}}$ & $13.90^{\mathrm{c}}$ & 0.324 \\
\hline
\end{tabular}

${ }^{\mathrm{z}}$ Please see Table 2 for the description of dietary treatment;

${ }^{y}$ SEM, standard error of means

${ }^{\mathrm{a}-\mathrm{c}}$ : Within a row, means without a common superscript letter differ $(\mathrm{P}<0.05)$

\section{DISCUSSION}

The growth performance of the broiler chickens as affected by dietary treatments in this study was consistent with observations of Saunderson and Mckinlay ${ }^{[18]}$ and Guo et al. ${ }^{[8]}$ who showed no difference in body weight between broilers fed diets supplemented with DL-methionine or DL-methionine + betaine. However, this experiment revealed that supplementation of BET to the diet of $15 \%$ Met deficiency increased growth rate of broilers at the starter phase as compared to that of chickens consumed the diet with normal level of Met (Control). Other studies also showed that supplementation of choline or BET increased ADG of birds fed diets marginally deficient in $\mathrm{Met}^{[19-20]}$. Furthermore, betaine is an osmolyte that could improve intestinal structure and function to increase growth performance ${ }^{[21,22]}$. It appears, thus, that BET and Met in marginally Metdeficient diets could lead to an equivalent growth response in broilers and that BET could spare a small portion of the Met.

It was interesting that all birds which had similar body weight at the end of 42-day experiment had the lower ADFI consuming Diet 3 compared to birds consuming Control diet and Diet 2. The reason for the reduced feed intake by BET when supplemented to diet of $25 \%$ Met deficiency but not of $15 \%$ Met deficiency is not known. The results, however, showed that the reduction of feed intake by BET did not negatively affect the growth of broiler chickens and therefore led to an improved feed efficiency by $4.34 \%$. Emmert et $a l .{ }^{[19]}$ found that feeding Met-deficient diets to chickens increased the activity of Betaine-HomocysteineMethyltransferase (BHMT) that specifically catalyses the transport of the preformed labile methyl group from the BET molecule to homocysteine that can be irreversibly transformed to cysteine for body protein synthesis and/or can be re-methylated by other methyl 
sources to form Met. It was also showed that supplementation of BET to chickens increased BHMT activity as well ${ }^{[23,24]}$. Therefore the improved feed efficiency with supplementation of BET to the diet of $25 \%$ Met deficiency is partially due to the joint action of Met deficiency and BET supplementation. The effect of BET supplementation on improving feed efficiency was consistent with its effect on increasing serum concentrations of $\mathrm{GH}$ and IGF-1 that have been demonstrated to be positively related to feed efficiency $^{[25,26]}$. Esteve-Garcia and Mack $^{[12]}$ also reported that BET supplementation improved feed efficiency. In contrast, Schutte et al. ${ }^{[27]}$ did not found positive effect of BET supplementation to the diets containing 0.05 or $0.10 \%$ added DL-Met on feed efficiency. Collectively, these results suggest that the effect of BET supplementation on feed efficiency may depend on diet composition, dietary level of Met and level of BET supplementation.

There are great variations regarding to what extent of dietary Met could be replaced by BET in broiler chickens, ranging from none to complete replacement. Differences in dietary composition especially level of Met, feeding management and health condition of the experimental birds may all attribute to the difference of chicks in responses to the replacement of Met with BET observed from these studies. The present study showed that up to $25 \%$ of dietary total Met could be replaced by BET without negatively affecting birds' growth performance.

The higher BMY of birds consuming Diet 3 compared to that of birds consuming Diet 2 or Control indicated that BET supplemented at the level of replacing $25 \%$ of the dietary Met increased the BMY at the end of 42-d growth period. This compared to the similar body weight and carcass yield of all treatments at the same age of the birds suggests that BET supplemented at the level of replacing $25 \%$ of dietary Met may have the positive effect on partitioning nutrients towards protein synthesis in breast meat. This hypothesis is supported by the elevated serum levels of $\mathrm{GH}$ and IGF-1 and increased protein content of the breast meat by this level of BET supplementation as that shown in Tables 4 and 6 and by the observation of Zhan ${ }^{[28]}$ who reported that BET supplementation increased GH and IGF-1 concentration in the blood. Growth hormone and IGF-1 have been well recognized to promote protein synthesis ${ }^{[29-31]}$. Other researchers also observed that BET improved breast meat yield ${ }^{[13]}$. On the contrary, Abdominal Fat Yield (AFY) as well as fat content in the liver was reduced, whereas fat content in the breast meat was increased by the supplementation of BET at the level of replacing $25 \%$ of dietary Met. These results were consistent with other reports ${ }^{[10,32]}$. However, Esteve-Garcia and Mack $^{[12]}$ reported that the effects of BET on breast yield and abdominal fat were small and non-significant while BET can significantly increase carcass yield. All of these indicated that growths of different tissues in broiler chickens responded to BET supplementation differently.

The exact mechanism that BET affects carcass composition is not clear. It has been proposed that the improvement of carcass lean percentage could be attributed to the increased availability of Met and cystine for protein deposition in BET-supplemented $\operatorname{diets}^{[13]}$. $\mathrm{Xu}$ and $\mathrm{Zhan}^{[23]}$ showed that BET supplementation enhanced the synthesis of methylated compounds such as carnitine that is required for the transport of fatty acids through the inner mitochondrial membrane where fatty acid oxidation takes place and that has been shown to reduce carcass and liver lipid content in pigs ${ }^{[33]}$. In addition, dietary supplementation of BET has been shown to support the synthesis of phosphatidylcholine that is a limiting element in the synthesis of Very Low Density Lipoprotein (VLDL) ${ }^{[34,}$

${ }^{35]}$ and VLDL prevents the deposition of fat in the liver and accelerates the removal of fat from the liver ${ }^{[36]}$. All of these could contribute to the alteration of carcass compositions observed in this study.

\section{CONCLUSION}

Broiler chickens fed diets with supplementation of BET at the level in replacing 15 or $25 \%$ of dietary Met had similar growth performance to the chickens fed diet of normal Met content over a 42-d feeding period. However, supplementation of BET at the level in replacing $25 \%$ of dietary Met increased concentrations of $\mathrm{GH}$ and IGF-1 in the serum and increased breast meat yield $(\%)$ and its protein and fat content, but reduced the fat content in the liver as compared to the non-BET supplemented diet of normal Met content. This study demonstrated that $25 \%$ of total Met in the diet that was formulated to meet the Met requirement based the Feeding Standard of P. R. China could be replaced by BET.

\section{REFERENCE}

1. Du Vigneaud, V., J.P. Chandler, A.W. Moyer and D.M. Keppel, 1939. The effect of choline on the ability of homocysteine to replace methionine in the diet. J. Biol. Chem., 131: 57-76. http://www.jbc.org/cgi/reprint/131/1/57.

2. Matthews, J.O. and L.L. Southern, 2000. The effect of dietary betaine in eimeria acervulina-infected chicks. Poult. Sci., 79: 60-65. http://ps.fass.org/cgi/content/abstract/79/1/60. 
3. Virtanen, E.I. and G.. Rumsey, 1996. Betaine supplementation can optimize use of methionine, choline in diets. Feedstuffs, 68: 12-13. http://www.fao.org/agris/search/display.do?f=./199 7/v2324/US9740514.xml;US9740514.

4. Pillai, P.B., A.C. Fanatico, M.E. Blair and J.L. Emmert, 2006. Homocysteine remethylation in broilers fed surfeit choline or betaine and varying levels and sources of methionine from eight to twenty-two days of age. Poult. Sci., 85: 1729-1736. http://poultsci.highwire.org/cgi/content/abstract/85/ 10/1729.

5. Ryan, N.D., T.A. Garrow and D.H. Baker, 2007. Betaine can partially spare choline in chicks but only when added to diets containing a minimal level of choline. J. Nutr., 137: 2224-2228. http://jn.nutrition.org/cgi/reprint/137/10/2224

6. McKeever, M.P., D.G. Weir, A. Molloy and J.M. Scott, 1991. Betaine-homocysteine methyltransferase: organ distribution in man, pig and rat and subcellular distribution in the rat. Clin. Sci., 81: 551-556. http://www.ncbi.nlm.nih.gov/pubmed/1657504

7. Pesti, G.M., A.E. Harper and M.L. Sunde, 1979. Sulfur amino acid and methyl donor status of cornsoy diets for starting broiler chicks and turkey poults. Poult. Sci., 58:1541-1547. http://www.ncbi.nlm.nih.gov/pubmed/575423

8. Guo, Y.M., X.B. Kuang, R.D. Xu and P.X. Yan, 1997. Studies of replacement value of betaine for methionine in broiler diets. China Feed, 2: 19-21.

9. Deng, Y.L. and Y.B. Weng, 1998. Effects of betaine instead of a portion of methionine on growth performance and carcass quality of broilers. Acta Zoonutrimenta Sinica, 59: 59.

10. Zhan, X.A., J.X. Li, Z.R. Xu and R.Q. Zhao, 2006. Effects of methionine and betaine supplementation on growth performance, carcase composition and metabolism of liquids in male broilers. British Poult. Sci., 47: 576-580. DOI: 10.1080/00071660600963438.

11. Gao, S.L., C.H. Shao, Y.E. Li and X.Y. Sun, 2006. Effects of different amount of betaine instead of methionine on broilers. Hubei J. Anim. Vet. Sci., 1: $10-11$

12. Esteve-Garcia, E. and S. Mack, 2000. The effect of DL-methionine and betaine on growth performance and carcass characteristics of broilers. Anim. Feed Sci. Technol., 87: 85-93. http://cat.inist.fr/?aModele $=$ afficheN\&cpsidt $=7948$ 64.

13. McDevitt, R.M., S. Mack and I.R. Wallis, 2000. Can betaine partially replace or enhance the effect of methionine by improving broiler growth and carcase characteristics? British Poult. Sci., 41: 473480.

http://www.ingentaconnect.com/content/tandf/cbps /2000/00000041/00000004/art00013 .
14. Wang, J. M., 2002. Animal Production Science: Determination of Poultry Carcass Quality. Agriculture Press, China, pp: 591-592.

15. Association of Official Analytical Chemists, 1990. Official Methods of Analysis. 15th. Edn., Assn. Offic. Anal. Chemists, Inc., Arlington, VA.

16. Toghyani, M., A. Khodami and A.A. Gheisari, 2008. Effect of organic and inorganic chromium supplementation on meat quality of heat-stressed broilr chicks. Am. J. Anim. Vet. Sci., 3: 62-67. http://www.scipub.org/fulltext/AJAV/AJAV326267.pdf.

17. SAS, 2000. User's Guide: Statistics. Release 8.1 Edn., SAS Institute Inc., Cary, NC., pp: 576. ISBN-10: 158025599X.

18. Saunderson, C.L. and J. McKinlay, 1990. Changes in bodyweight, composition and hepatic enzyme activities in response to dietary methionine, betaine and choline levels in growing chicks. Br. J. Nutr., 63: 339-349.

19. Emmert, J.L., T.A. Garrow and D.H. Baker, 1996. Hepatic betaine-homocysteine methyltransferase activity in the chicken is influenced by dietary intake of sulfur amino acids, choline and betaine. J. Nutr., 126: 2050-2058. http://jn.nutrition.org/cgi/content/abstract/126/8/20 50

20. Pesti, G.M., A.E. Harper and M.L. Sunde. 1980. Choline/methionine nutrition of starting broiler chicks. Three models for estimating the choline requirement with economic considerations. Poult. Sci., 59: 1073-1081. http://www.ncbi.nlm.nih.gov/pubmed/7393840.

21. Honarbakhsh, Shirin, Mojtaba Zaghari and Mahmood Shivazad, 2007. Can exogenous betaine be an effective osmolyte in broiler chicks under water salinity stress? Asian-Aust. J. Anim. Sci., 20: 1729-1737.

http://cat.inist.fr/?aModele $=$ afficheN\&cpsidt $=1921$ 0440.

22. Zulkifli, I, S.A. Mysahra and L.Z. Jin, 2004. Dietary supplementation of betaine(betafin) and response to high temperature stress in male broiler chichens. Asian-Aust. J. Anim. Sci., 17: 244-249. http://www.cababstractsplus.org/google/abstract.as $\mathrm{p} ? \mathrm{AcNo}=20043011660$

23. Xu, Z.R. and X.A. Zhan, 1998. Effect of betaine on methionine and fat metabolism in broiler chickens. Acta Vet. Zootech. Sinica, 29: 212-219.

24. Wang, Y.Z., Z.R. Xu and J. Feng, 2000b. Study on the effect of betaine on meat quality and the mechanism in finishing pigs. Scientia Agric. Sinica, 33: 94-99. http://www.ceps.com.tw/ec/ecjnlarticleView.aspx? atliid=139551\&issueiid=10284\&jnliid=1004 
25. Wang, Y.Z. and Z.R. Xu, 1999. Effects of feeding betaine on weight gain and carcass trait of barrows and gilts and approach to mechanism. J. Zhejiang Agric. Univ., 25: 281-285. http://www.fao.org/agris/search/display.do?f=./200 0/v2601/CN1999302740.xml;CN1999302740.

26. Yu, D.Y., J. Feng and Z.R. Xu, 2001. Effects of betaine on fat and protein metalbolism in different stages of swine. Chinese J. Vet. Sci., 21: 200-203. http://scholar.ilib.cn/Article.aspx?AIT=QCode\&AI $=$ zgsyxb200102027\&A=zgsyxb200102027

27. Schutte, J.B., J. de Jong, W. Smink and M. Pack, 1997. Replacement value of betaine for DLmethionine in male broiler chicks. Poult. Sci., 76: 321-325. http:// ps.fass.org/cgi/content/abstract/76/2/321.

28. Zhan, X.A., 2000. Studies on growth-promoting mechanism of betaine in broiler chickens. Acta Agric. Zhejiangensis, 12: 209-212. http://www.fao.org/agris/search/display.do?f $=. / 200$ 2/v2807/CN2001300251.xml;CN2001300251

29. Wang, M.Y., 1987. Hormone biochemistry: Proteohormone. People's Medical Publishing House, pp: 75-81.

30. Machlin, L.J., 1972. Effect of porcine growth hormone on growth and carcass composition of the pig. J. Anim. Sci., 35: 794-800. http://jas.fass.org/cgi/content/abstract/35/4/794.

31. Evock, C.M., T.J. Caperna and N.C. Steele, et al., 1991. Influence of time of injection of recombinant procine somatotropin (rpst) relative to time of feeding on growth performance, hormone and metabolite status and muscle RNA, DNA and protein in pigs. J. Anim. Sci., 69: 2443-2451. http://jas.fass.org/cgi/content/abstract/69/6/2443.
32. Feng, J., X. Liu, Y.Z. Wang and Z.R. Xu, 2006. Effects of betaine on performance, carcass characteristics and hepatic betaine-homocysteine methyltransferase activity in finishing barrows. Asian-Aust. J. Anim. Sci., 19: 402-405. http://cat.inist.fr/?aModele $=$ afficheN\&cpsidt $=1761$ 3089.

33. Owen, K., J. Nelssen, R. Goodband, T. Weeden and S. Blum, 1996. Effect of L-carnitine and soyabean oil on growth performance and body composition of early weaned pigs. J. Anim. Sci., 74:

1612-1619. http://jas.fass.org/cgi/content/abstract/74/7/1612.

34. Sparks, J.D. and C.E. Sparks, 1994. Insulin regulation of triacylglycerol-rich lipoprotein synthesis and secretion. Biochim. Biophys. Acta, 1215:

9-23. http://www.ncbi.nlm.nih.gov/pubmed/7948013.

35. Yao, Z. and R.S. McLeod, 1994. Synthesis and secretion of hepatic apolipoprotein B-containing lipoproteins. Biochim. Biophys. Acta, 1212: 152166. http:// www.ncbi.nlm.nih.gov/pubmed/8180241.

36. Yao, Z. and D.E. Vance, 1989. Head group specificity in the requirement of phosphatidylcholine biosynthesis for very low density lipoprotein secretion from cultured hepatocytes. J. Biol. Chem., 264: 11373-11380. http://www.jbc.org/cgi/reprint/264/19/11373. 